International Journal of Agriculture, Environment and Bioresearch

Vol. 4, No. 06; 2019

ISSN: $2456-8643$

\title{
HERITAGE AND TOURISM: WHAT ACTIONS FOR SUSTAINABLE TOURISM IN THE TERRITORY OF HILLS?
}

\author{
Louis DJEGBATE ${ }^{1}$, Sylvain VISSOH ${ }^{\mathbf{2}}$, Norbert AGOINON ${ }^{\mathbf{1}}$ and Alain ZINGONGO ${ }^{\mathbf{1}}$ \\ ${ }^{1}$ Laboratory of Spatial Planning, Environment and Sustainable Development (LATEDD), Department of Geography \\ and Territorial Planning (DGAT), University of Abomey-Calavi (Benin). \\ ${ }^{2}$ Urban and Regional Dynamics Studies Laboratory (LEDUR), Department of Geography and Territorial Planning
}

(DGAT), University of Abomey-Calavi (Benin).

http://doi.org/10.35410/IJAEB.2019.4491

\begin{abstract}
The sustainable development of a territory by promoting the tourism sector requires an inventory of the tourist attractions and potentials of this territory. The objective of this research is to contribute to a better understanding of the tourist and ecotourism potential of the hill territory for the purpose of their promotion for local development. The methodology used combines documentary research and field work. This work consisted in making a survey through a preliminary visit then in-depth inquiries at the level of resource persons, individual interviews with the mayors and direct observations in the field. The data processing was done thanks to SPSS software, Arc -View and Excel. The analysis of the results was carried out based on the SWOT or FFOM (Strengths, Weaknesses, Opportunities and Threats) model. The results show that the territory of the hills, with an area of 13,951 square kilometers, has important tourism resources generated by its geography and history: 196 tourist resources have been identified and can be classified into three (3) main categories, namely natural landscapes, historic sites and monuments, folklore, habits and customs. These three categories respectively represent $13.76 \%$, $23.18 \%$ and $29.71 \%$ of the tourism resources of the territory. The development and implementation of an effective strategy to develop this rich potential will develop the tourism sector and therefore strengthen the local economy in this territory.
\end{abstract}

Keywords: Hill Territory, Benin, tourist potential, local economy.

\section{INTRODUCTION}

The sustainable development of the tourist heritage of a territory is an important factor of economic development and improvement of the living environment of the populations.

As such, Dupont (2001) asserts that tourism resources constitute the basic condition for tourism development. These resources, though unrelated to tourism, nevertheless determine the attractiveness of a region, hence the need to establish a precise inventory of these resources, both quantitative and qualitative, in order to adopt policy of conscious and rational development of these. For Gillet (2011), a tourist destination is any accessible tourist territory, which includes accommodation, transport infrastructure, as well as activities, activities and services. 
Tourism resources induce tourism activities which sometimes require ad hoc or global development, with a rational definition of the equipment to be installed.

The territory of the hills, vast of $13.951 \mathrm{~km} 2$ has a great diversity of natural and human resources. However, two important questions arise: what is the tourism value of these resources? What can be done to further promote these resources for tourism purposes?

\section{DATA AND METHODS}

\subsection{Geographical framework of the study}

The territory of the Hills lies in the central region of Benin between $1^{\circ} 40$ 'and $2^{\circ} 15^{\prime}$ east longitude, and $8^{\circ} 20$ 'and $8^{\circ} 50^{\prime}$ north latitude. It is composed of six (06) communes namely: Bantè, Dassa-Zoumè, Glazoué, Ouèssè, Savalou and Savè all dotted with hills, hence its name of department of the Hills. It is limited to the north-west by the department of Donga, to the northeast by that of Borgou, to the east by the Federal Republic of Nigeria, to the west by that of Togo, to the southwest by the department from Zou and to the southeast by that of the Plateau (Figure1).

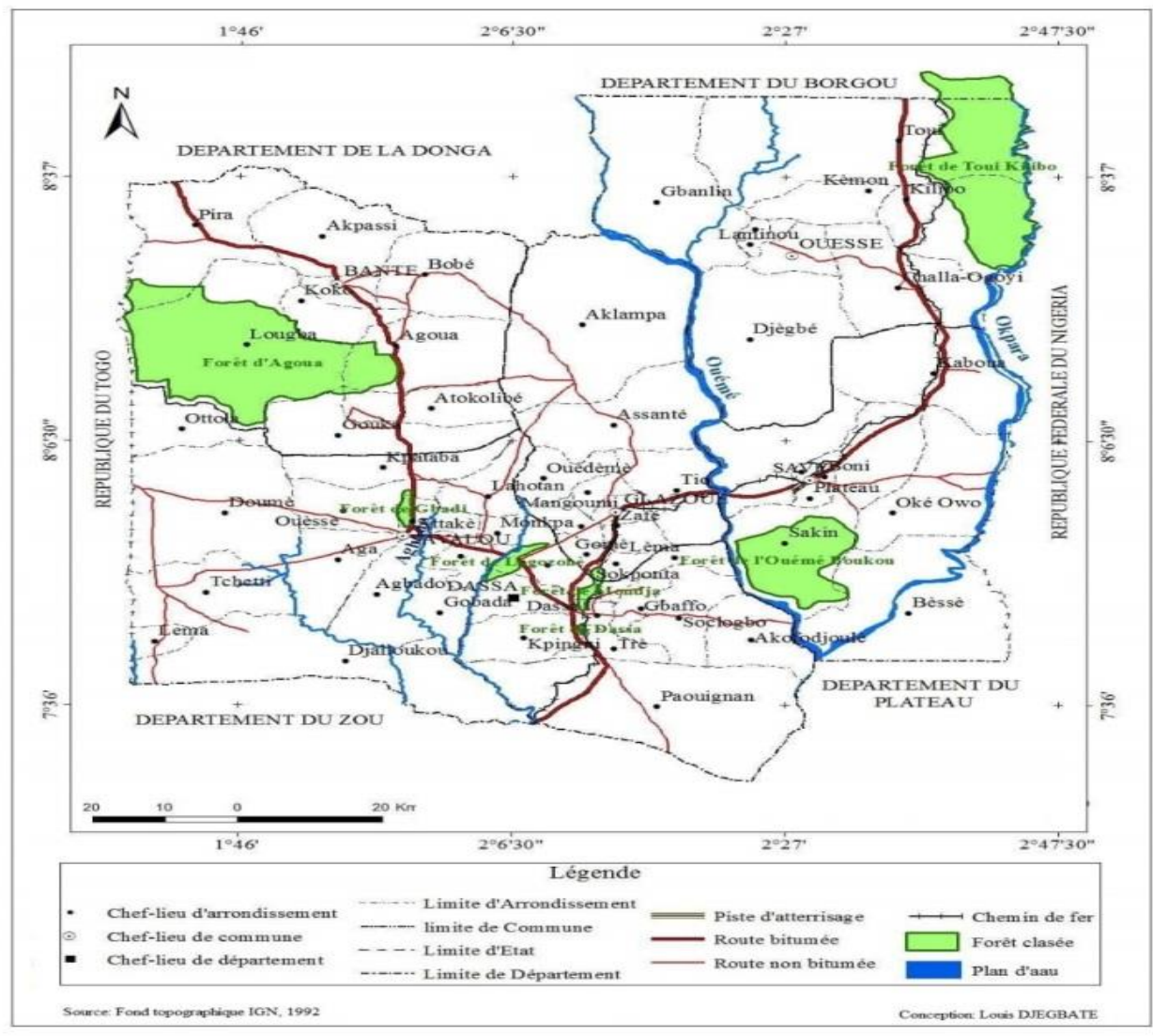

Figure 1: Location of the Hills territory 


\section{NATURE OF DATA COLLECTED}

The data collected within the framework of this study relate to the tourist sites and attractions of the hills which combine: historical monuments (fortifications, private residences), public or collective infrastructures (markets, churches), places of memory having ethnographic value (houses, places of worship, sanctuaries), natural resources and geological formations (caves, vegetation, etc.), gastronomy, songs and dances etc. The data also covered the methods of management of these resources by local governments.

\subsection{Techniques and materials for data collection}

Several research techniques were used in this work. These are the documentary research, the direct observations in the field, the interviews with the six (06) mayors of the department, the questionnaires addressed to twelve (12) communal agents and 18 actors of territorial structures for the promotion of tourism. In addition, the reasoned choice technique made it possible to interview 211 resource persons across the six communes of the department according to the following criteria:

- have lived on the territory of the Hills during the last ten years.

- be a cultural promoter practicing on the territory with a seniority of at least ten (10) years;

- be an actor in the local development of the territory;

A total of 247 people were interviewed for this research.

\subsection{Data processing and results analysis}

At the end of the survey work, the completed data collection sheets were grouped by target and were tabulated.

Qualitative data was subject to content analysis; a simple statistical treatment was carried out on the quantitative data through the frequency calculation according to the formula $\mathrm{F}=(\mathrm{ni} / \mathrm{N}) \mathrm{x}$ 100 where $\mathrm{F}$ designates the frequency, nor the number of persons having provided the answer $\mathrm{i}$ and $\mathrm{N}$ the total number of respondents. The results obtained were analyzed using the SWOT or FFOM (Strengths, Weaknesses, Opportunities and Threats) model. Criteria for prioritization (originality / authenticity, accessibility, historical roots, state of conservation / cleanliness, recognition / reputation, territorial representativeness, publicity around the resource, tourist flows, integration into tourist circuits, potential demand), evaluation resources followed by the application of weights were applied to the inventoried resources for better characterization.

\section{RESULTS}

The territory of the Hills abounds with an undeniable tourist potential due to its history, its geomorphology, its fauna, its flora, the know-how of its population. Of great tourist and ecotourism value, these sites and attractions need to be known and valued in order to make the territory a mandatory stop on the way to the northern part of the country. Some attractions can be observed through the boards 1 and 2 below 


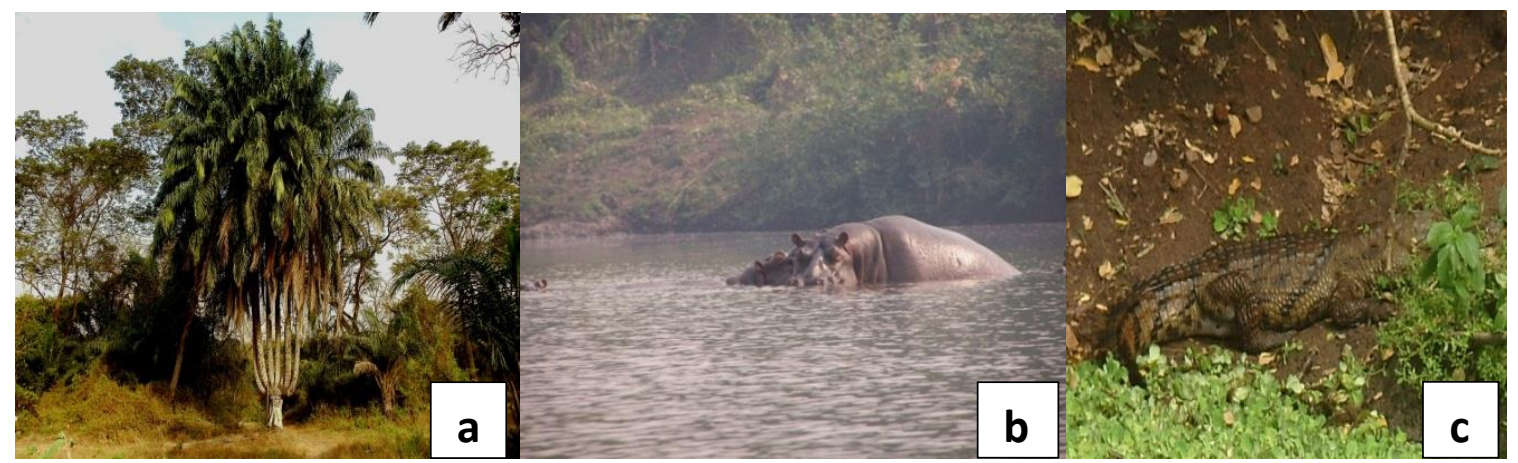

Board: 1: Landscape and wildlife with ecotourism value

a-Palm tree with 7 trunks of Miniki / Savalou, b-Hippopotamus in the Ouémé river Bètèkoukou / Dassa-Zoumè, c- Crocodile of the pond with the crocodiles of Savalou. Shooting: Djègbatè L., February 2019.

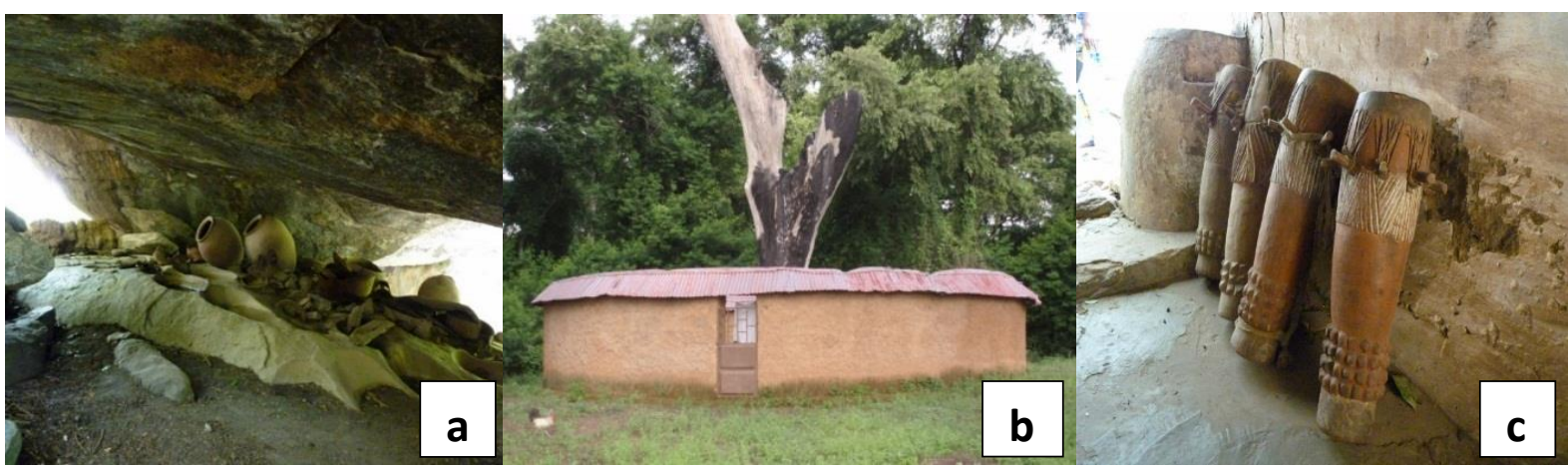

Plate 2: Material Cultural Heritage

a- historical vestiges of the Queens in the refuge hills at Dassa-Zoumè, b- Site of enthronement of the kings of Savalou, c-Drums associated with worship in Dassa-Zoumè.

Shooting: Djègbatè L., June 2019.

\subsection{Typology and location of sites and attractions}

From natural sites to architectural creation, from crafts to works of art such as painting and sculpture, from songs to literature and musical research, different cultural universes are likely to contribute to the supply of eco-tourism products. on the territory of the Hills.

Real estate resources - the best known, considered the most threatened by the current upheavals sites, historical or artistic ensembles, isolated monuments in their geographical setting or their immediate environment, all ingredients that participate in the construction of the branding of the destination. 
Overall, inventory work has identified 196 sites and tourist attractions. They are concentrated in $47.95 \%$ in the municipality of Savalou, $24.48 \%$ in Dassa-Zoumè and incidentally in the other communes namely, Ouèssè, Bantè, Glazoué with respectively $10.20 \%, 7.14 \%, 5.61 \%$ and Savè $4.59 \%$.

\subsection{Categorization of inventoried resources}

By categories, the sites, attractions, cultural events, local gastronomy, songs and dances with eco-tourism value inventoried on the territory of the Hills are as follows:

$13.76 \%$ of the resources correspond to famous sites. Historical monuments: fortifications, private residences; public or collective infrastructure: squares, markets, bridges; churches, etc. ;

$23.18 \%$ represent places of memory with a high ethnographic value: dwellings, places of worship, shrines, etc. ;

$29.71 \%$ constitute natural resources and geological formations: caves, vegetation, etc. They are also considered as resources of scientific interest;

28.98\% relate to the gastronomic richness, the songs and the dances which one finds in particular in vodoun.

Figure 2 presents these results by categories.

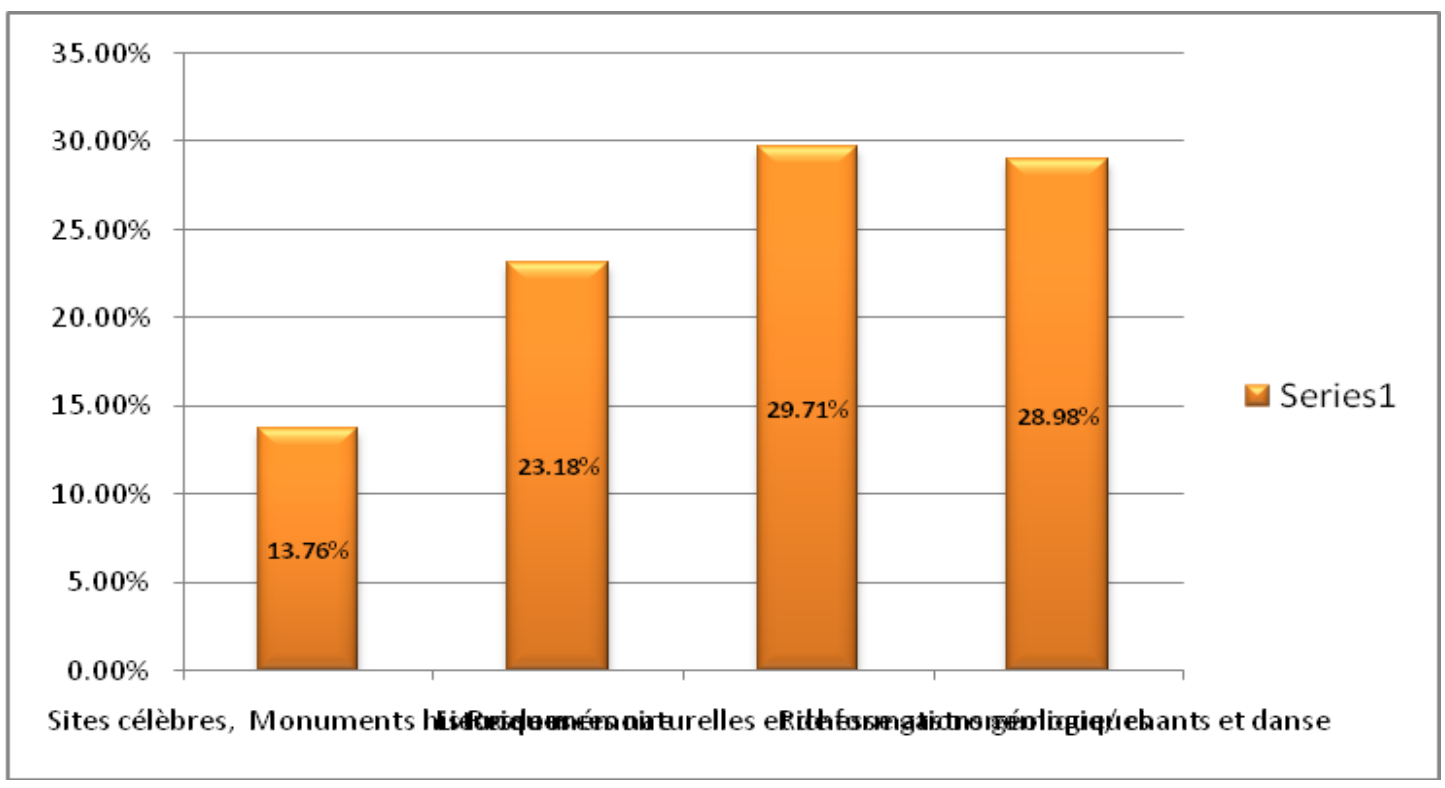

Figure 2: Distribution by categories of inventoried resources

\subsection{Geographic concentration of inventoried resources}

The distribution of resources, all categories combined by local authority of the Hills is presented graphically as below: 


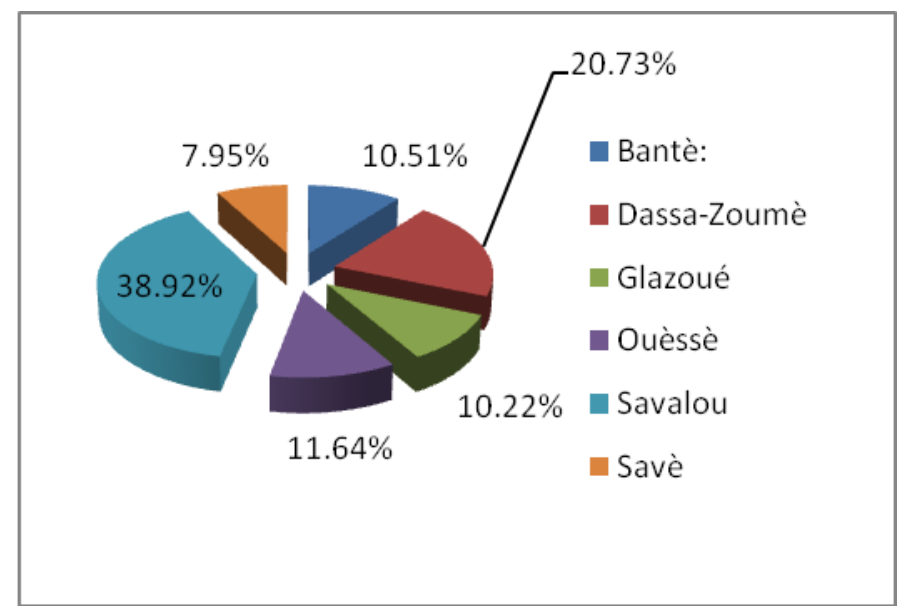

Figure 3: Geographic concentration of resources by Municipality of the territory

The eco-tourism resources of all categories in the Collines territory are concentrated mainly in two municipalities, namely: Savalou (38.92\%) and Dassa-Zoumè (20.73\%). These communes are followed respectively in order of importance of concentration of eco tourism potentialities of the commune of Ouèssè $(11.64 \%)$, Bantè $(10.51 \%)$, Glazoué $(10.22 \%)$ and the municipality of Savè $(7.95 \%)$. by this geographical concentration, one can conclude that the municipalities of Savalou and Dassa-Zoumè are the main tourist poles of the territory and if, the communal authorities become more aware of the importance of the socio-economic effects of the activity on the populations they will make it a promising sector to support local development.

\subsubsection{Distribution of resource categories in local authorities}

Célèbres Famous sites and historic monuments are mainly concentrated in the communes of Savalou 39.47\% and Dassa-Zoumè (23.68\%). The rest are scattered in Bantè and Savè (10.52\%), Glazoué and Ouèssè (7.89\%). The representation of the data for this resource category is shown in Figure 4 below.

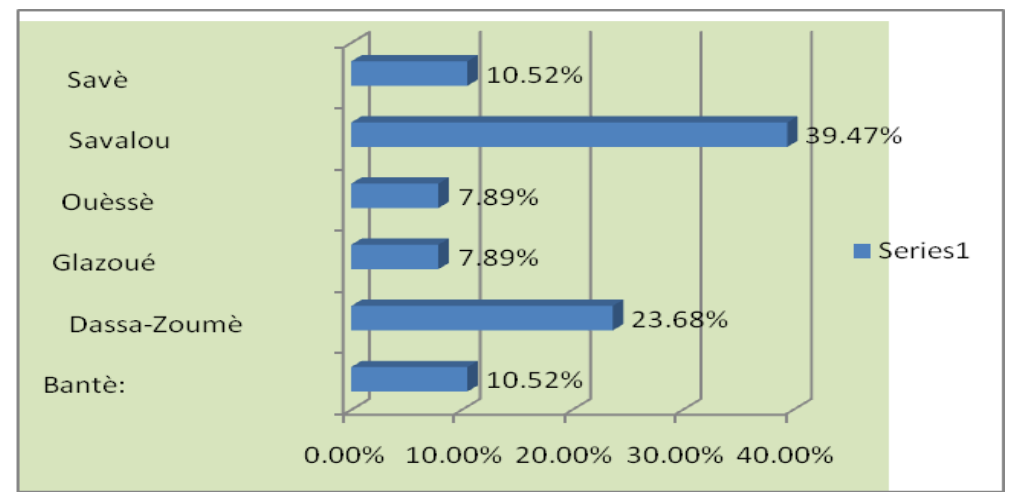

Figure 4: Distribution of famous sites and historical monuments by municipality of the territory 
The Communes of Savalou and Dassa-Zoumè alone concentrate on their territory $81.24 \%$ of the places of memory ie (59.37\%) in Savalou and (21.87\%) in Dassa-Zoumè. The remaining $18.76 \%$ of this resource category is distributed in Bantè (6.25\%), Glazoué and Savè in equal shares of $(4.68 \%)$ and Ouèssè $(3.12 \%)$. The distribution of high ethnographic memory sites in the Hills is shown in Figure 5 below.

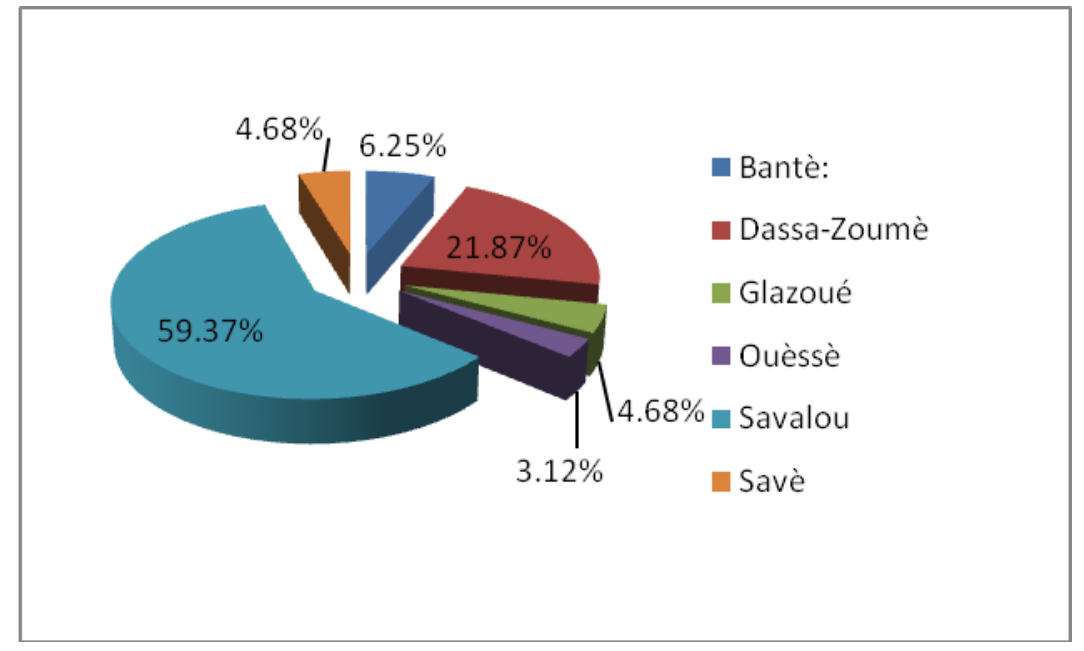

Figure 5: Distribution of places of memory by hill town

Natural resources and geological formations.

As its name indicates (territory of the Hills), there exists in all the territorial collectivities of the region, geological formations of great value eco-tourist strengthened by the natural resources in this case the vegetal cover favorable to the scientific tourism. However, these natural resources and geological formations are more represented in the municipalities of Savalou (43.90\%) and Dassa-Zoumè (29.26\%). The commune of Ouèssè concentrates (14.63\%) of this category of resources. The rest of these resources, ie $12.21 \%$, are distributed over Glazoué (6.09\%), Bantè $(3.65 \%)$ and Savè $(2.43 \%)$. The relative importance of resources is shown in Figure 6 below.

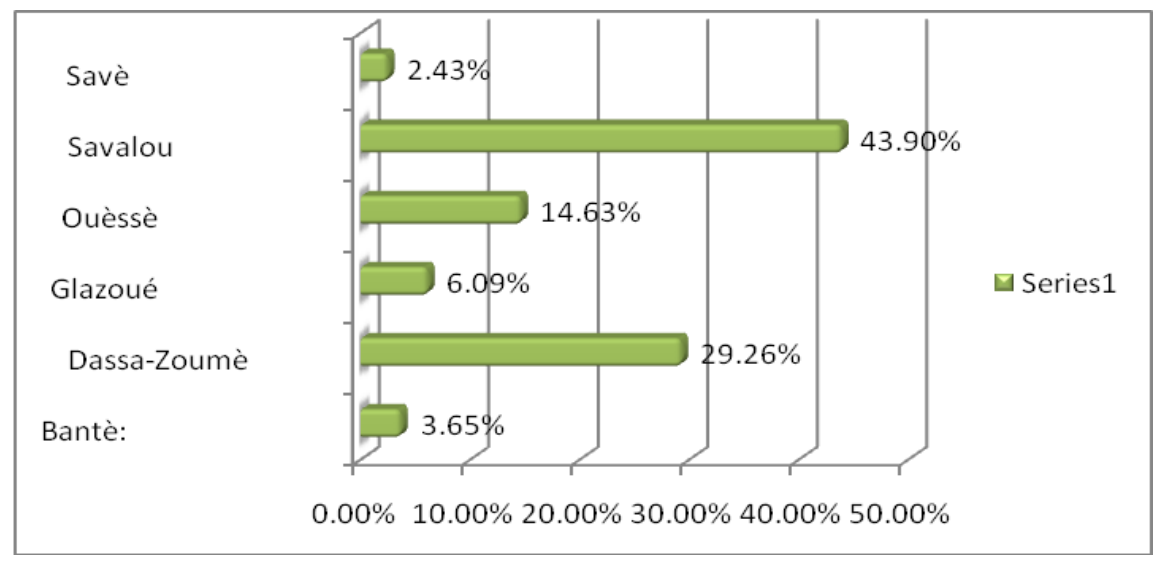

Figure 6: Distribution of natural resources and geological formations by Commune 


\section{Gourmet wealth, songs and dances}

The gastronomic richness of the Hills is special and almost common to all the territory. This gastronomic wealth is based on the culinary identity of the territory: yam and its derivatives. It can be pounded and seasoned with seed sauce (peanut (Arachishypogaea), sesame (Sesamumindicum), etc.) accompanied by the sticky Corchorusolitorius (horsehair), Abelmoschusesculentus (okra), etc. or herbal sauces: tea Gambia in French or in the local fungi language (tchiayo / kiyoyo) whose scientific name is: Ocimumgraticimum, Ocimum basilicum (akohoun), (aklala / aglala). It can also be fried.

Gastronomy is also based on the paste made from corn with the various derivatives that are: red paste, bomiwo, wofleflé (in local language), etc. The gastronomy on the territory is well provided and present on all the territory as it is represented on the following figure 7.

The songs, rhythms and dances are as rich and diversified as the gastronomic wealth. In the six (06) local authorities of the Hills, 58 rhythms and dances are inventoried.

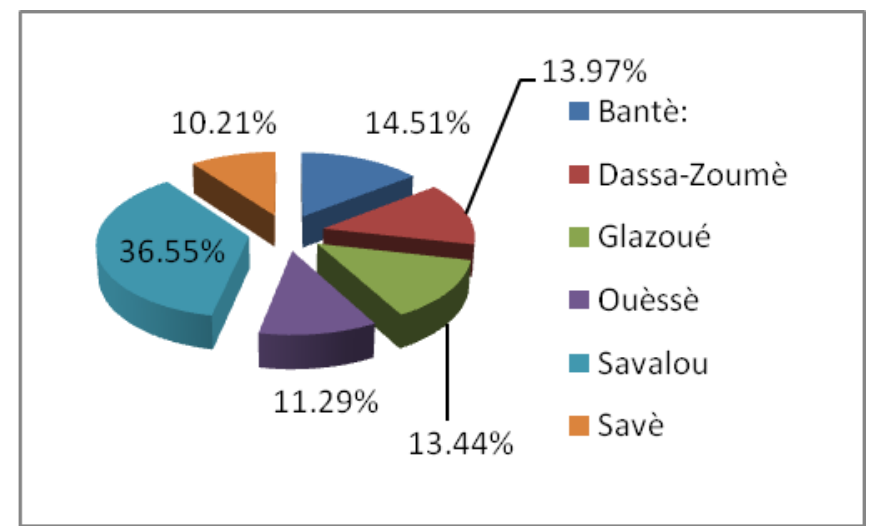

Figure 7: Summary of gastronomic richness, songs / dances by municipality in the Collines area

\subsubsection{Prioritization of inventoried resources in the Collines territory}

The analysis of the collected data allowed to classify the resources in four levels according to the respect of the criteria of originality / authenticity, accessibility, historical anchorage, state of conservation / cleanliness, recognition / notoriety, territorial representativity, advertising around the resource, tourist flows, insertion into tourist circuits, potential demand. Level I meets at least 8 of the 10 criteria, Level II meets at least 6 of the 10 criteria, Level III meets at least 4 of the 10 criteria and Level IV meets at least 2 of the 10 criteria. As shown in Figure 8 below, Tier I resources make up $2.53 \%$ of inventoried resources, Tier II resources: $2.89 \%$, Tier III resources: $4.34 \%$, and Tier IV resources. , $21 \%$. 


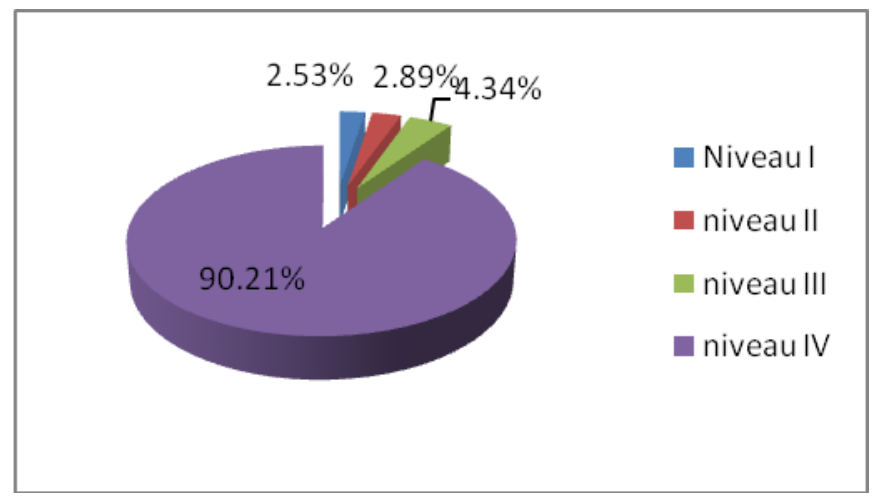

Figure 8: Prioritization of inventoried resources in the Collines territory

It appears from reading Figure 8 that $90.21 \%$ of the resources inventoried are of level IV. This means that these resources are attractions that can contribute to better development of other resources. They are dormant resources that meet at least 2 of the 10 criteria defined in the weighting section. Exploitation of these resources is possible on the condition of a very significant investment. Level III resources represent $4.34 \%$ of the total resources inventoried in the Hills. These are dormant resources that meet at least 4 of the 10 criteria defined in the weighting. This means that these resources have some characteristics that are likely to attract visitors to the region for reasons other than tourism. Interest in these resources is determined based on their proximity to other important elements, their historical roots or their reputation. Level II represents $2.89 \%$ of the resources whose characteristics are likely to attract visitors who will come to the region. Their interest is also determined based on their proximity to other important elements, their historical roots or their reputation. These resources are dormant, classified at level 3, they meet at least 4 of the 10 criteria defined in the processing and analysis part of the results. The $2.53 \%$ of the resources inventoried are of level I. These tourism resources are exceptional and of great importance for the tourism sector at national or even international level; they are capable of arousing a wave of local or foreign visitors; they are operated as is with a minimum of investment. They meet at least 8 of the 10 weighting criteria. However, after implementing a participatory tourism development plan, these resources can be better exploited.

It can be concluded after analysis that more than three quarters (3/4) or $90.21 \%$ of inventoried resources are attractively low and without significant investment, they will not bring significant added value for the well-being of local communities. Of all the resources inventoried, only $2.53 \%$ have an attraction likely to attract visitors and help promote tourism in the Hills. In this category of level I, there are attractions such as the royal palace of Savalou, the site of the Pantheon of the Pan-African resistance, the hunting and fa culture museum, the palm tree with seven trunks, the twin hills, the site of the Marian pilgrimage. in Dassa-Zoumè, the village of Koko in Bantè, the site of Know and Protect Nature (CPN) butterflies in Glazoué. This situation challenges local governments; they would benefit from directing investments for the recovery of the sector in the territory.

Figure 9 below shows the spatial distribution of resources in the study environment. 
Vol. 4, No. 06; 2019

ISSN: $2456-8643$

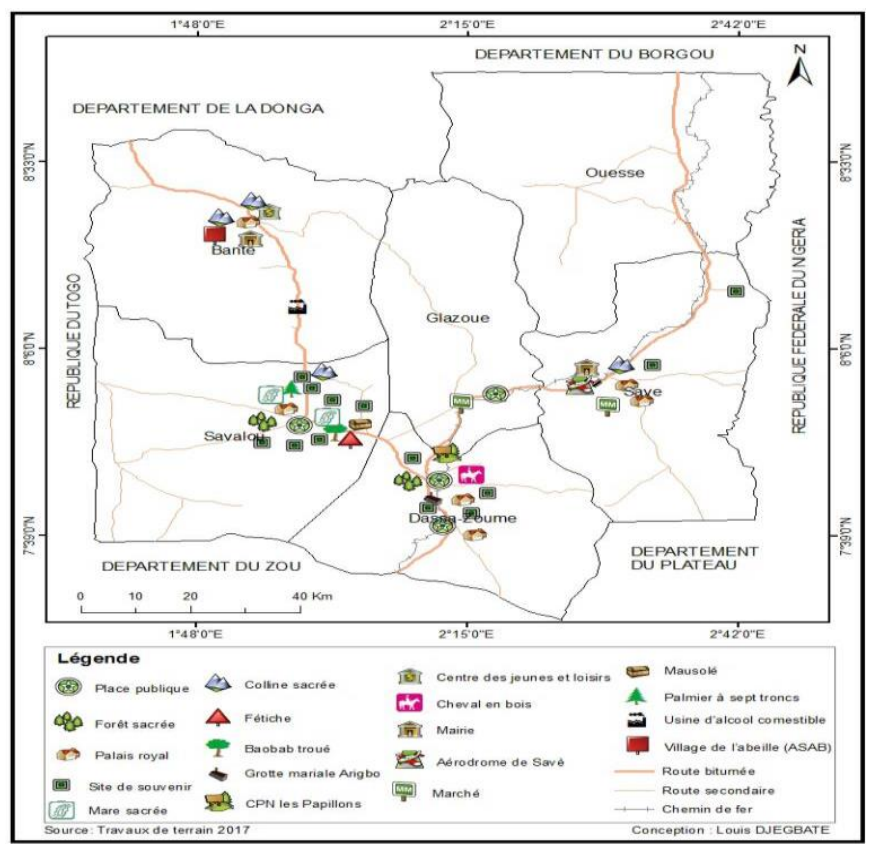

Figure 9: Distribution of sites and tourist attractions of the territory of the Hills

\subsubsection{Hierarchical distribution of complementary infrastructures}

Compared to the analysis of complementary resources, such as accommodation, catering and structures for promoting ecotourism in the territory, the trends by level appear as follows (Figure $10)$.

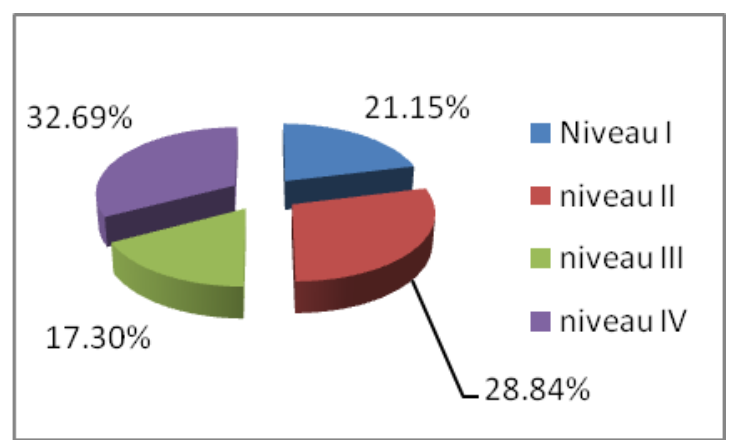

Figure 10: Hierarchical distribution by level of complementary infrastructure

Accommodation, catering and level I tourist offices represent $21.15 \%$ of the offer and are mainly concentrated in the municipalities of Dassa-Zoumè and Savalou; those of level II represent $28.84 \%$. The combined levels III and IV total $49.99 \%$ of the accommodation offer. It emerges from this analysis that despite the importance of the accommodation structures inventoried on the territory, just $21.15 \%$ are of an acceptable level and meet the amenities to be able to accommodate the foreigner. We can mention in this category, structures such as hotels JECO, Miracle and the shadow of the Marian sanctuary in Dassa-Zoumè, the hotels F \& F, Calypso- 
Benin and Reference in Savalou, Bethel motel, Ambassadeur hotels and Rive des Collines in Glazoué and Prestige and Joy in Savè. The structures of level II are moderately acceptable, those of levels III and IV are structures of the lower class but which at given periods of the year help to heal the image of the Hill destination by strengthening the capacity of reception of the territory.

\section{DISCUSSION}

Several authors have carried out inventory work on heritage properties and tourist attractions in regions and have come up with results similar to those of this research. Indeed, for UNESCO (1972), the best way to create tourist flows is to make the attractions known. For Dupont (2001), the inventory is the structuring and evaluation instrument by which knowledge of resources is accessed. It consists in identifying and describing in a summary or in-depth manner, and by means of more or less sophisticated techniques, the different components of a heritage circumscribed within a geographic, historical, social and economic space. .

Above all, it aims to shed adequate light on a phenomenon or set of phenomena requiring intervention, such as the application of a protective measure, a rehabilitation strategy, financial support or, quite simply, enhancement work. of the resource through information.

Goeldner R. (2000) lists the resources that can be exploited for tourism. These resources are natural, cultural, historical, etc. Because they are located in a certain geographic area, the territory of the Hills, it can be characterized by its tourist development. You can organize activities there that will attract tourists.

The exploitation of the tourist resource generates more added value if it is part of a development scheme where the immediate environment is endowed with infrastructures, equipment, services, animation, interpretation, etc. LanquarR. (1985).

In short, for the development of the tourism sector, all the authors are unanimous on the need to know the sites and attractions of the space through a directory before claiming to make it a factor of development of the territory.

\section{CONCLUSION}

The inventory of tourist potential in the hills, carried out as part of this research shows that this territory has a diversified attraction potential, but concentrated at $72.44 \%$ in the municipalities of Savalou and Dassa-Zoumè; which gives these municipalities a position of tourist pole of the territory.

These tourism resources, particularly those of levels I and II, must be enhanced through a participatory tourism development policy for the territory. It should be noted that the measures to be adopted to make tourism resources more attractive must imperatively be designed so as not to alter or destroy the character of the site because, foreign tourists are more attracted by an intact nature and culture.

\section{REFERENCES}


Colvin J.G., 1996 - Local ecotourism: The Capirona program in the province of Napo, Ecuador. Una Sylva ${ }^{\circ} 187$

Iroko Y. O., (2008): "What is ecotourism and why should the state and local communities promote it? ", The Environment, Lomé, MERF, $\mathrm{n}^{\circ} 011,8$ p.

Kassa B.D., 2001 - Enumeration techniques and factors determining the modeling of the dynamics of wild fauna in the dense semi-deciduous forest of the Lama. Dissertation of DESS, FSA-univ. nat. Benin, Abomey-Calavi, 82 p.

Koutinhouin E. S., (2006): Cultural Heritage and Tourism Development, Study, 28 p.

Kpédénou K. D., (2009): Eco-tourism developments and conservation of Togolese coastal ecosystems. Master's thesis, LaRBE, University of Lomé, 98 p.

Kurt K., (1993): The concept of ecotourism, Cahiers d'Espaces, P.214.

Lougbégnon O. T., and Houessou L., (2009): Basic study on the good management of Agonvè ecosystems, report, Cotonou, Benin, $54 \mathrm{p}$.

Savalou Town Hall, (2009): Savalou Municipality Tourism Development Strategy, study, 68p

Marien B., and Beaud J.P., (2003): A Practical Guide to the Use of Statistics in Research: The Case of Small Samples, AUF, Quebec, $44 \mathrm{p}$.

Mayi E. A., (2007): Urban tourism territories: The practice of tourism stakeholders in the cities of Amboise, Blois and Tours, doctoral thesis, University of Angers, $439 \mathrm{p}$.

Mekati H., (2013): To what extent can tourism in mountain areas contribute to the local development of Kabylia? Master1 thesis in local development, tourism and heritage development, UMM of Tizi-Ouzou, Algeria, 140 p.

Nobimè G., 2002 - Collection of basic data for the protection of the red-bellied monkey in the Lama Classified Forest in Benin. DEA thesis, Environmental management, Flash, AbomeyCalavi, $72 \mathrm{p}$.

Norris R., 1992 - It's Green, it’s Trendy: Can ecotourism save natural areas? National

Parks 66 (1-2): 30-34;

UNWTO, (2002): World Ecotourism Summit, Final Report, 150 p.

UNWTO, (2002): Contribution of the World Tourism Organization to the world summit for sustainable development, Johannesburg, $62 \mathrm{p}$.

UNEP, (2011): Tourism and Mountains: A Practical Guide to Managing the Environmental and Social Impacts of Mountain Excursions, France, p. 11. 